\title{
Transposition flap for correction of ectopic breast in Poland's syndrome using a pre-molded silicone prosthesis
}

\author{
Retalho de transposição para correção de mama ectópica em síndrome de \\ Poland usando prótese de silicone pré-moldada
}

\author{
José Humberto Cardoso \\ RESENDE $^{1}$ \\ ROMMEL ApOLINÁRIO \\ FeITOSA $^{2}$ \\ Ricardo SOUZA CruZ²
}

Study conducted at the Hospital dos Servidores do Estado, Rio de Janeiro, RJ, Brazil.

Submitted to SGP (Sistema de Gestão de Publicações/Manager Publications System) of RBCP (Revista Brasileira de Cirurgia

Plástica/Brazilian Journal of Plastic Surgery).

Received: January 22, 2010 Accepted: April 26, 2010

\begin{abstract}
The authors report a variation of Poland's syndrome with ectopic right breast. Three surgeries were performed at different times: transposition flap to place the mammary gland in an anatomic position; reduction of the contralateral left breast; and implantation of a premolded silicone prosthesis to correct the malformation caused by the absence of the major and minor pectoral muscles. The surgeries were performed at six-month intervals, and the final outcome was new and acceptable positioning of the breasts.
\end{abstract}

Keywords: Poland syndrome. Musculoskeletal abnormalities. Breast implantation. Breast implants.

\section{RESUMO}

Os autores apresentam uma variante da síndrome de Poland com mama direita ectópica. Foram realizados três tempos cirúrgicos: retalho de transposição para colocação da glândula mamária em posição anatômica; redução da mama contralateral esquerda; e implantação de prótese de silicone pré-moldada para correção do defeito causado pela agenesia dos músculos peitoral maior e peitoral menor. Com intervalo de seis meses entre as cirurgias, o resultado final apresenta novo posicionamento aceitável das mamas.

Descritores: Síndrome de Poland. Anormalidades musculosqueléticas. Implante mamário. Implantes de mama.

\section{INTRODUCTION}

Anatomically normal female breasts are cone-shaped and located in the midclavicular line of the chest. Each breast has a papillary-areolar complex with a diameter between $3 \mathrm{~cm}$ and $5 \mathrm{~cm}$ and ranging in color and size according to the characteristics and physiological state of each person.

The anomaly in the case presented herein refers to a variation of Poland's syndrome described by Alfred Poland in 1841 . This variation is rarely associated with absence of the serratus muscle or brachysyndactyly. The most common feature is the absence of the pectoralis major muscle and the occasional absence of the pectoralis minor muscle with reduction of the mammary gland size on the side of agenesis. To correct the reported case, two transposition flaps in a "Z" form were used for replacement of the mammary gland in the anatomical position. The incidence of this syndrome in the population is $1: 30,000$ and is more common among women ${ }^{1-6}$. These malformations may result from rupture of the subclavian arterial supply during pregnancy.

Several variations of Poland's syndrome have been described:

- bilateral absence of the mammary gland and unilateral agenesis of the pectoralis major muscle;

1. Plastic surgeon, full member of the Brazilian Society for Plastic Surgery, Chairman of the Plastic Surgery Service of the Hospital dos Servidores do Estado, Rio de Janeiro, RJ, Brazil.

2. Plastic surgeon, specialist member of the Brazilian Society for Plastic Surgery, Rio de Janeiro, RJ, Brazil. 
- unilateral absence of the mammary gland with a rudimentary papillary-areolar complex and non-existent pectoralis major and minor muscles on the agenesis side;

- absence of the pectoralis major muscle and rudimentary breast with contralateral breast hypertrophy;

- unilateral absence of pectoralis major and minor muscles with rudimentary and ectopic breast with contralateral breast hypertrophy, as in the described case (Figures 1 to 3 ).

Other variants can be found in Poland's syndrome in relation to breast size and absence of one or both pectoral muscles.

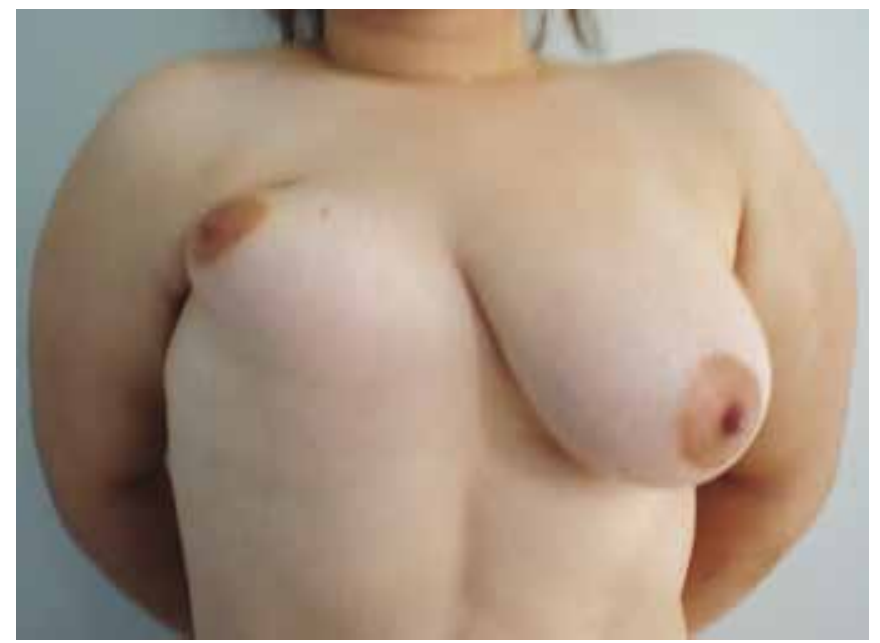

Figure 1 - Front view of the ectopic and rudimentary breast with contralateral mammary hypertrophy.

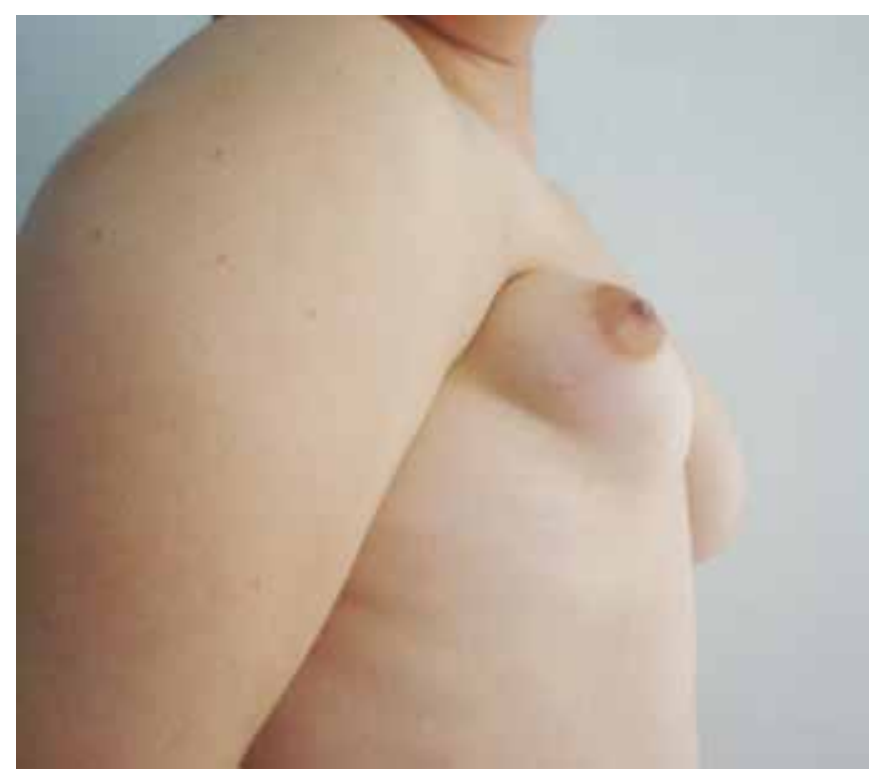

Figure 2-Overview of the right profile.

\section{Features of Poland's Syndrome}

The features of this syndrome include hemithorax with an uneven and concave shape resulting from the absence of the pectoralis major muscle in one side of the chest and, less frequently, the pectoralis minor muscle, with hypomastia or mammary agenesis or other deformities that are usually congenital ${ }^{7}$.

The most frequent complaints are aesthetic, with loss of upper limb movements ${ }^{8}$.

\section{CASE REPORT}

A 22-year-old nulliparous Caucasian woman with an ectopic and reduced breast presented with absence of the pectoralis major and minor muscles on the right side. The intervention was achieved using two flaps: one above and other below. After detachment, the flaps were rotated by transposition and resembled a large Z-plasty or Holmstrom's flap at the bottom; this is a widely used in reconstruction technique (Figure 4).

To correct the imperfection caused by the absence of muscles, a pre-molded prosthesis was prepared using a plaster powder mixed with water that was later used to prepare a silicone prosthesis by a specialized company (Figure 5). This specialized prosthesis was used to correct the concavity resulting from agenesis of the muscle because the simple placement of a typical commercial prosthesis may not correct a deformity of the large axillary part.

After the right side was reconstructed, a mammaplasty was carried out on the contralateral side for correction of the volume asymmetry caused by the left breast. The transposition was the first-step surgical procedure (Figure 6). After six months, the second step of the surgical procedure involved

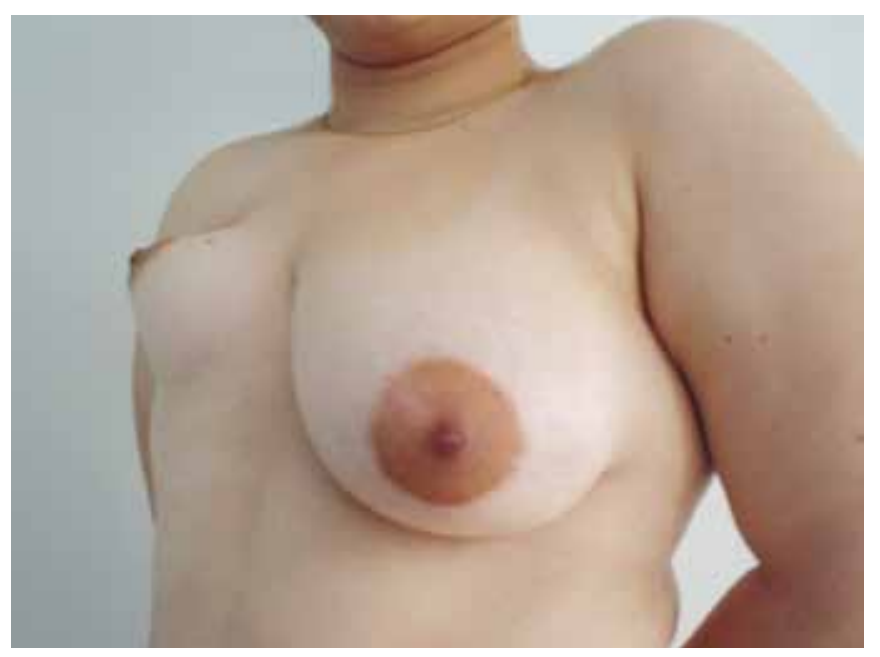

Figure 3 -Oblique and left view showing the difference between the two breasts. 
reduction of the left breast, and finally, placement of the premolded silicone prosthesis was the third step.

The main surgical steps are illustrated in Figures 5 to 9 . These three surgical steps were performed at

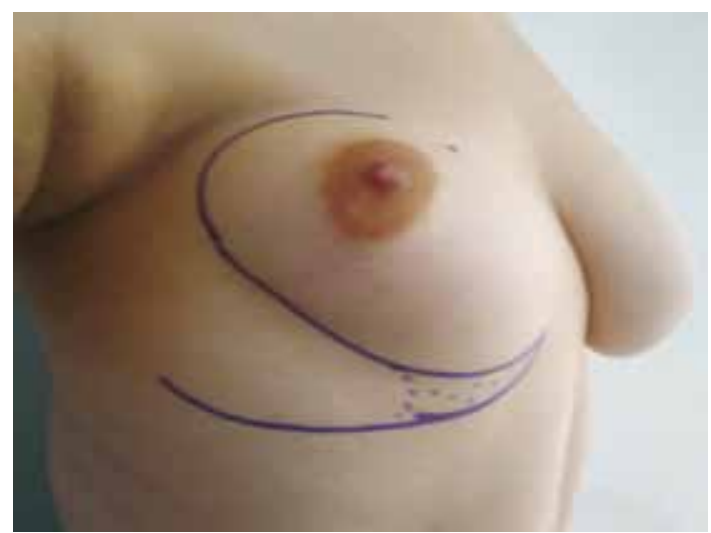

Figure 4 - Preoperative aspect with design of flaps from the first surgical procedure.

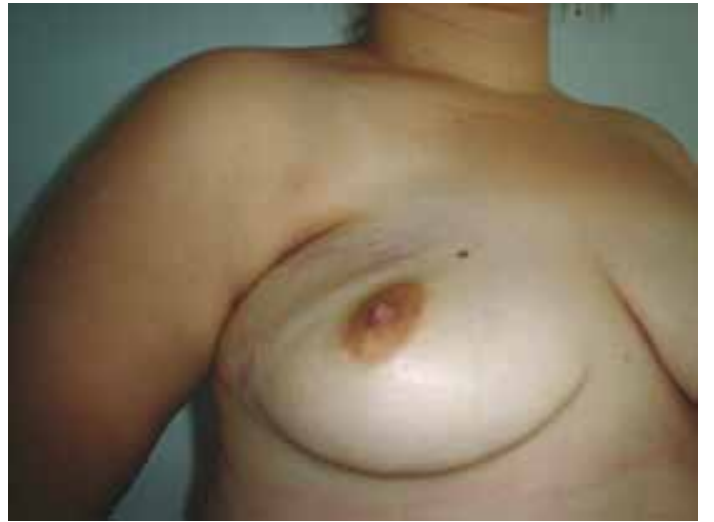

Figure 5 - Postoperative appearance one month after the first surgical procedure following flap rotation.

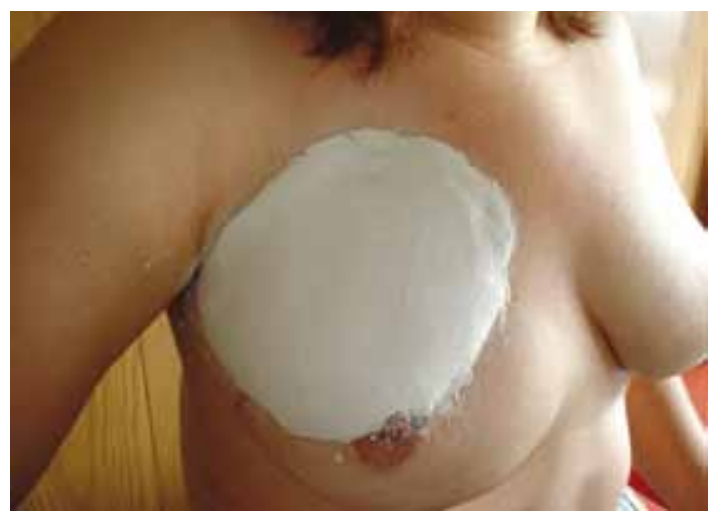

Figure 6 -Plaster mold for preparing the prosthesis confection. intervals of six months. The images of pre- and postoperative periods demonstrate the anatomical differences and changes after the intervention (Figures 1 to 4 and 10 to 13$)$.

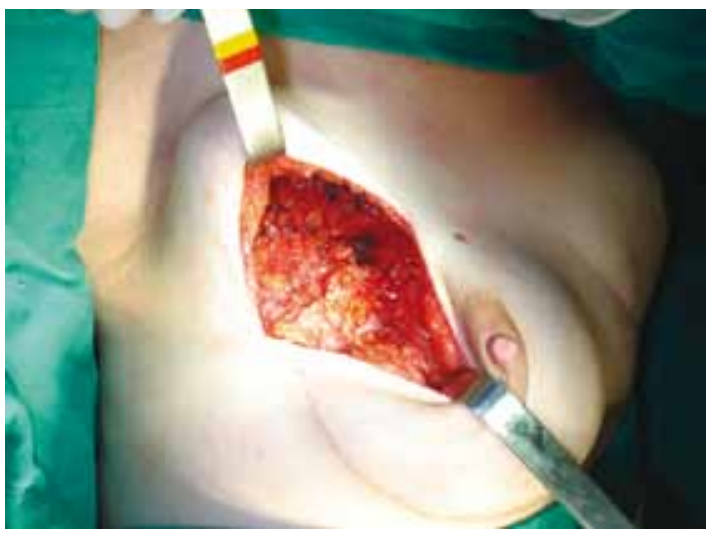

Figure 7 - Intraoperative aspect of the space to be filled by the prosthesis.

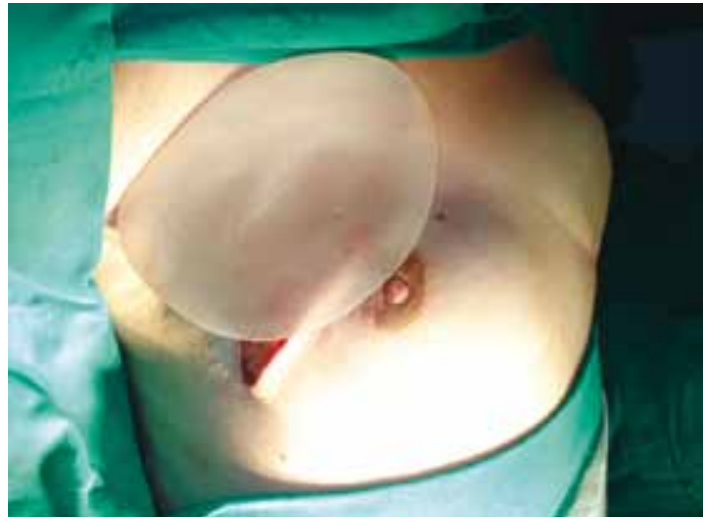

Figure 8 -Intraoperative aspect of the pre-molded silicone prosthesis.

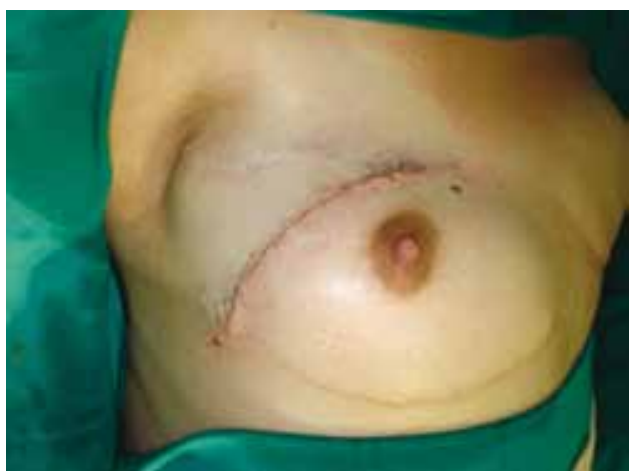

Figure 9-Immediate postoperative aspect after the third procedure. 


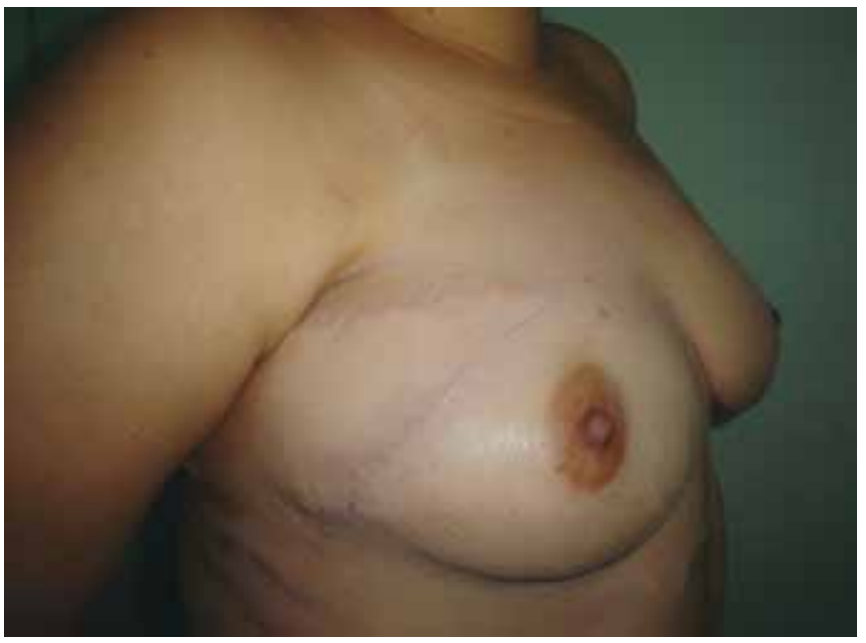

Figure 10 - Final result: oblique and right views six months postoperatively.

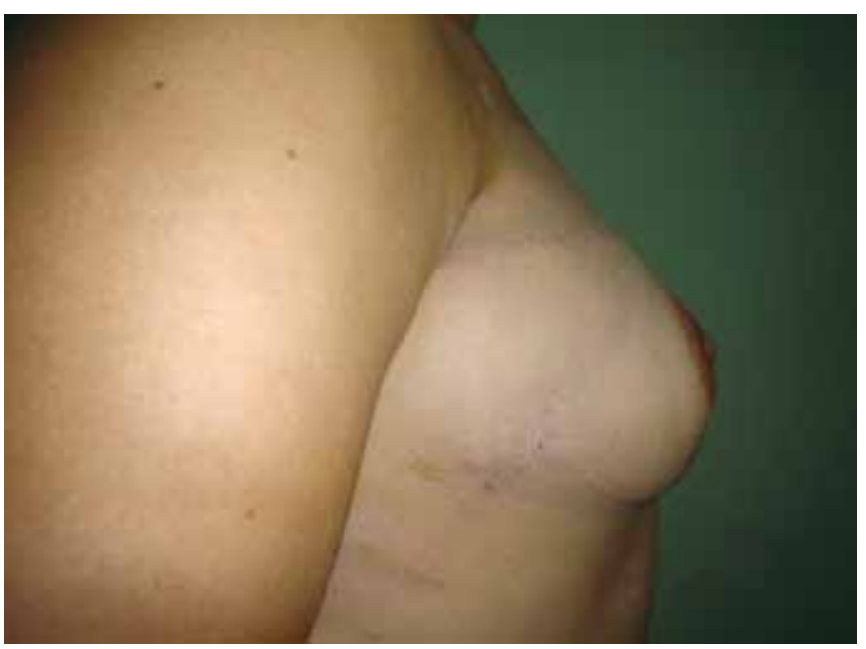

Figure 11 - Final result: profile and right views six months postoperatively.

\section{DISCUSSION}

Many surgical techniques could have been chosen to correct the deformities of the patient reported herein ${ }^{8-12}$. The transposition of two flaps with the pre-molded prosthesis insertion was the chosen procedure.

This procedure, which involved three surgical steps performed at six-month intervals, was discussed and approved by the patient during the preoperative period after receiving an explanation of the postoperative benefits.

Transposition flaps and rotations are widely used in reconstructions of both the mammary gland and the chest wall. In the case reported herein, after flap rotation, the marking resembled a " $Z$ " of the classic Z-plasty and Holmstrom's

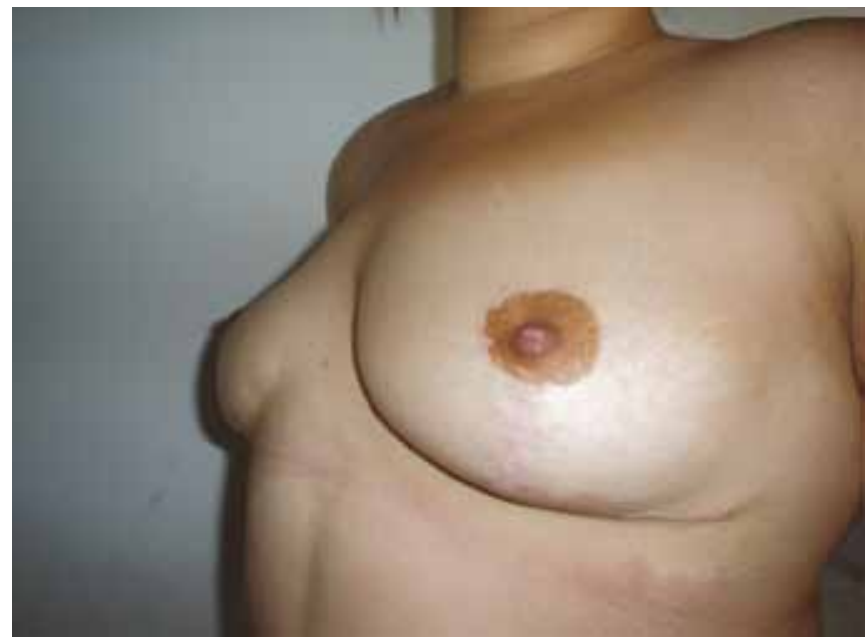

Figure 12 - Final result: oblique and left views six months postoperatively.

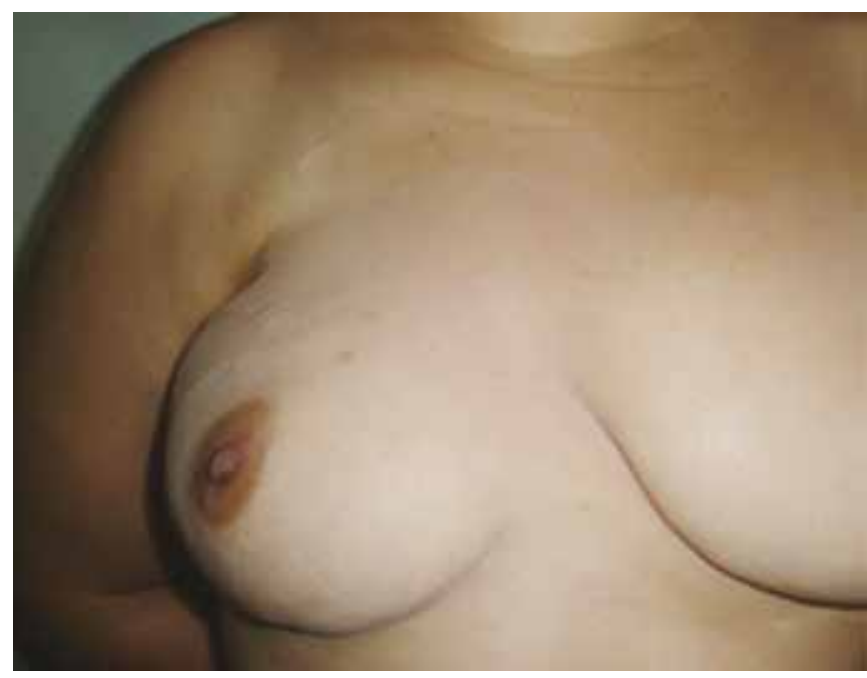

Figure 13 - Final result: frontal view six months postoperatively.

marking at the bottom of the flap. The use of a silicone prosthesis pre-molded with plaster powder facilitated correction of the axillary concavity. This procedure can be used for other types of correction and reconstruction of congenital or acquired physical defects.

The final result was considered satisfactory by the patient and justifies the possible difficulties found for the definition of the technique to be chosen.

\section{REFERENCES}

1. Baker JL Jr, Mara EJ. Simultaneous correction of the chest wall deformity and prosthetic augmentation mammaplasty in a case of Poland's syndrome. Br J Plast Surg. 1976;29(4):347-51. 
2. Boaz D, Mace JW, Gotlin RW. Poland's syndrome and leukaemia. Lancet. 1971;1(7694):349-50.

3. Castilla EE, Paz JE, Orioli EM. Pectoralis major muscle defect and Poland complex. Am J Med Genet. 1979;4(3):263-9.

4. David TJ. Nature and etiology of the Poland anomaly. N Engl J Med. 1972;287(10):487-9.

5. Gaubert J, Rochiccioli P, Bardier M, Cassignol D, Dutau G, Guitter H. The Poland' syndrome (7 cases). Chir Pediatr. 1978;19(3):13543.

6. Mace JW, Kaplan JM, Schamberger JE, Gotlin RW. Poland's syndrome. Report of seven cases and review of the literature. Clin Pediatr (Phila). 1972;11(2):98-102.

7. Saxena NC. Ectopia cordis child surviving: prosthesis fails. Pediatric New. 1976;10:3.
8. Urschel HC Jr. Poland's syndrome. Chest Surg Clin N Am. 2000;10(2):393-403.

9. Valdatta L, Fidanza C, Thione A, Benedetta B, Reguzzoni M, Protasoni M. Experimental study in rats: does varying the hardness of a silicone implant affect the type of capsule that surround it? Plast Reconstr Surg. 2006;117(3):1076.

10. Borschel GH, Costantino DA, Cederna PS. Individualized implant-based reconstruction of Poland syndrome breast and soft tissue deformities. Ann Plast Surg. 2007;59(5):507-14.

11. Gautam AK, Allen RJ Jr, Lo Tempio MM, Mountcastle TS, Levine JL, Chiu ES. Congenital breast deformity reconstruction using perforator flaps. Ann Plast Surg. 2007;58(4):353-8.

12. O'Donoghue JM, Bahia H, Bunsell RP, Regan PJ. Intrapleural bupivicaine in latissimus dorsi breast reconstruction. Ann Plast Surg. 2008;61(3):252-5.

Correspondence to:

José Humberto Cardoso Resende

Rua Rodolfo Dantas, 16/1001 - Copacabana - Rio de Janeiro, RJ, Brazil - CEP 22020-040

E-mail: jresen99@hotmail.com 